Abstracta Iranica

Revue bibliographique pour le domaine irano-aryen

Volume 27 | 2006

Comptes rendus des publications de 2004

\title{
« Book Translations as a Cultural Activity in Iran 1806-1896 ». Iran, 41 (2003), pp. 279-289.
}

\section{Rudi Matthee}

\section{(2) OpenEdition \\ 1 Journals}

Édition électronique

URL : http://journals.openedition.org/abstractairanica/5931

DOI : 10.4000/abstractairanica.5931

ISSN : 1961-960X

\section{Éditeur :}

CNRS (UMR 7528 Mondes iraniens et indiens), Éditions de l'IFRI

\section{Édition imprimée}

Date de publication : 15 mai 2006

ISSN : 0240-8910

\section{Référence électronique}

Rudi Matthee, « «Book Translations as a Cultural Activity in Iran 1806-1896 ». Iran, 41 (2003), pp. 279-289. », Abstracta Iranica [En ligne], Volume 27 | 2006, document 159, mis en ligne le 02 janvier 2007, consulté le 25 septembre 2020. URL : http://journals.openedition.org/abstractairanica/5931 ; DOI : https://doi.org/10.4000/abstractairanica.5931

Ce document a été généré automatiquement le 25 septembre 2020.

Tous droits réservés 


\section{« Book Translations as a Cultural Activity in Iran 1806-1896 ». Iran, 41 (2003), pp. 279-289.}

\section{Rudi Matthee}

1 This pioneering article provides intriguing insight into the energy with which Iranian intellectuals and bureaucrats set out to translate key works of European science, history-writing, philosophy, geography, and literature in the 19th century. The author suggests that the first translations, mostly involving books on military history and biographies of great men, were produced in the first decade of the century, and notes how much of the activity was court-sponsored, with especially Nasir al-Din Shah taking a personal interest in the results. The article also provides important information on the ways in which the translations remained imbued with traditional notions of proper style and idiom, leading to creative adaptation ranging from titles sounding like traditional ones to persianized proper names or even altered names, and the employment of devices such as synonyms and flowery locutions.

\section{INDEX}

Thèmes : 4.2.1. Safavides et Qâjârs 
AUTEURS

RUDI MATTHEE

University of Delaware 